1968

\title{
Selective Conscientious Objection: Divine Will and Legislative Grace
}

Hugh MacGill

University of Connecticut School of Law

Follow this and additional works at: https://opencommons.uconn.edu/law_papers

Part of the Law and Politics Commons, Law and Society Commons, and the Military, War, and Peace Commons

\section{Recommended Citation}

MacGill, Hugh, "Selective Conscientious Objection: Divine Will and Legislative Grace" (1968). Faculty Articles and Papers. 255.

https://opencommons.uconn.edu/law_papers/255 


\section{HEINONLINE}

Citation: 54 Va. L. Rev. 13551968

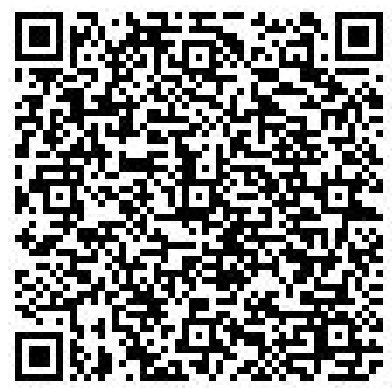

Content downloaded/printed from

HeinOnline (http://heinonline.org)

Mon Aug 15 17:09:05 2016

-- Your use of this HeinOnline PDF indicates your acceptance of HeinOnline's Terms and Conditions of the license agreement available at http://heinonline.org/HOL/License

-- The search text of this PDF is generated from uncorrected OCR text.

-- To obtain permission to use this article beyond the scope of your HeinOnline license, please use:

https://www.copyright.com/ccc/basicSearch.do?

\&operation $=$ go\&search Type $=0$

\&lastSearch $=$ simple\&all $=$ on\&titleOrStdNo $=0042-6601$ 
SELECTIVE CONSCIENTIOUS OBJECTION: DIVINE WILL AND LEGISLATIVE GRACE

\author{
Hugb C. Macgill*
}

A MAN who is willing to bear arms against whomever his governical system of which he is a part. A man obedient to his government in all temporal matters save participation in war, and who bases that exception on an extra-political allegiance owed principles derived from "religious training and behief," is similarly accounted no threat to the state. But difficult questions attend the conceptual status of a man obedient to the state in all matters save participation in some wars, who reserves to himself the right to decide which wars permit his participation and demands that the political system accommodate him in this respect. Is this man to be regarded as one imbued with a discriminating conscience, tolerable within the political system, or as a damned rebel who substitutes his political judgment for that of the officers and organs duly authorized to judge such matters?

Increasing numbers of people eligible for the draft assert a qualitative difference between fighting Hitler and fighting Ho Chi Minh, and profess themselves conscientiously opposed to participation in the war in Vietnam. Two such persons have already appeared in the courts. ${ }^{1}$ As long as the United States alters neither its foreign policy nor its system of conscription, noore dissidents are likely to surface. Analysis of this phenomenon, the "selective conscientious objector," compels an assessment of the power-or the right-of the state to require an individual to violate his own conscience, but to date the courts have not given this problem the candid treatment it deserves. It may be useful, then, to attempt a determination of the legal validity of an asserted right of selective conscientious objection.

\title{
Background of the Conscientious Objector Exemption
}

The scope of the present exemption for conscientious objectors and its underlying premises have developed through interaction of federal

\footnotetext{
* B.A., 1965, Yale University; LL.B., 1968, University of Virginia; Reginald Heber Smith Community Lawyer Fellow, Baltimore, 1968-69. Mr. Macgill served in the United States Army from 1960 to 1963.

1 Noyd v. McNamara, 378 F.2d 538 (10th Cir.), cert. denied, 389 U.S. 1022 (1967); United States v. Kurki, 384 F.2d 905 (7th Cir. 1967), cert. denied, 390 U.S. 926 (1968).
} 
statutes and court decisions concerning what constitutes religion and what role religion plays in the political sclieme. ${ }^{2}$ Congress first provided such an exemption in $1864,{ }^{3}$ and revised its standards in the Draft Act of 1917. ${ }^{4}$ The 1917 statute exempted members of

any well-recognized religious sect or organization ... whose existing creed or principles forbid its members to participate in war in any form and whose religious convictions are against war . . . 5

This provision followed the 1864 statute in requiring botl membership in a "peace church" and personal adherence to that church's tenets, and added the "war in any form" language-the requirement of total pacifism. ${ }^{6}$

The exemption was broadened in the Selective Training and Service Act of $1940^{7}$ to cover anyone "who, by reason of religious training and belief, is conscientiously opposed to war in any form." 8 Strenuous efforts to broaden it still further by dropping the implicit requirement of organized religious affiliation were rejected. ${ }^{9}$

\footnotetext{
- 2 See generally National Service Board for Religious Objectors, Congress Looks at the Consctenttous Objector (1943); 2 Selectrve Service System, Special Monograph No. 11, Backgrounds of Selectrve Service (1947); Conklin, Conscientious Objector Provisions: $A$ View in the Light of Torcaso v. Watkins, 51 Geo. L.J. 252 (1963).

3 The statute extended the exemption to members of religious denominations who shall by oath or affirmation declare that they are conscientiously opposed to the bearing of arms, and who are prohibited from doing so by the rules and articles of faith and practice of said religious denominations . . . .

Act of Feb. 24, 1864, ch. 13, \$17, 13 Stat. 9. Those who qualified under the Act were to be drafted as noncombatants or, in the alternative, might pay a commutation fee of 300 dollars. Id.

4 Act of May 18, 1917, ch. 15, 40 Stat. 76.

5 Id. $\$ 4$, at 78. By Executive Order No. 2823, the exemption was extended to conscientious religious objectors without regard to affiliation with peace churches, Exec. Order No. 2823 (1918), as under the 1940 Act. Selective Training and Service Act of 1940, ch. $720, \$ 5(\mathrm{~g}), 54$ Stat. 889.

${ }^{6}$ An effort was made in the Senate to extend the exemption to all persons opposed to war by reason of conscience, rather than by conscience and sectarian affiliation, but it failed to pass. 55 CoNg. REc. 1478-79 (1917).

7 Ch. 720,54 Stat. 889.

$8 \mathrm{Id}$. at $\$ 5(\mathrm{~g})$.

9 The adopted language, proposed by the American Society of Friends, was preferred by Congress over the American Civil Liberties Union's suggestion that anyone "conscientiously opposed to war in any form" should be entitled to the exemption. Hearings on H.R. 10132 Before the House Comm. on Military Affairs, 76th Cong., 3d Sess. 191, 211 (1940). Evidently Congress was willing to forego the requirement of peace church affiliation, but not to admit mere "conscience" as a permissible basis for claiming the exemption. See Conklin, supra note 2, at 269-70.
} 
When the "religious training and belief" language came before the courts, however, conflict developed over its breadth. In United States v. Kauten, ${ }^{10}$ the Second Circuit had no trouble holding that an atheist whose scruples against participation in World War II stemmed primarily from an acute distaste for President Roosevelt was not within the exempting language. But Judge Augustus Hand, in dictum, interpreted the statute to confer an exemption on any individual whose "conscientious scruple against war in any form [was] a response ... to an inward mentor, call it conscience or God. ..." ${ }^{11}$ Judge Hand's dictum, which found the statute to be quite as broad as Congress clearly intended it should not be, became the law of the Second Circuit in United States ex rel. Reel v. Badt. ${ }^{12}$ The Ninth Circuit, on the other hand, remained true to congressional intent, holding in Berman v. United States ${ }^{13}$ that "philosophy and morals and social policy without the concept of deity cannot be said to be religion ..." for purposes of exemption under the 1940 Act. ${ }^{14}$

10133 F.2d 703 (2d Cir. 1943).

11 Judge Hand's dictum read as follows:

$[\mathrm{T}]$ he provisions of the present statute ... take into account the characteristics of a skeptical generation and make the existence of a conscientious scruple against war in any form, rather than allegiance to a definite religious group or creed, the basis of exemption. . . .

There is a distinction between a course of reasoning resulting in a conviction that a particular war is inexpedient or disastrous and a conscientious objection to participation in any war under any circumstances. The latter, and not the former, may be the basis of exemption under tle Act. The former is usually a political objection, while the latter, we think, may justly be regarded as a response of the individual to an inward mentor, call it conscience or God, that is for many persons at the present time the equivalent of what has alId. at 708 . ways been thought a religious impulse.

For an expression of regret at the damage Judge Hand's language does to the idea of a conscientious selective objector, see Potter, Conscientious Objection to Particular Wars, 4 Religion and the Public Order 44, 60-63 (1968). Dr. Potter describes the decision as "a misstep possessing the marks of tragedy." Id. at 60 .

12141 F.2d 845 (2d Cir. 1944). The court described Reel as a philosophical liumanitarian who did not believe in a deity, and testimony confirmed that he was not religious. Despite these facts, the court lield Reel entitled to the exemption. See also United States ex rel. Phillips v. Downer, 135 F.2d 521, 524 (2d Cir. 1943), where the facts were unclear but Judge Hand's dictum was treated as a rule permitting the inclusion of nontheistic humanists within the exemption.

13156 F.2d 377 (9th Cir.), cert. denied, 329 U.S. 795 (1946).

14 Herman Berman's sincerity and conscientiousness were not contested, but Herman Berman did not believe in God, nor even in a god. The court of appeals, with the Second Circuit's decision in Kauten before it, held Berman not entitled to the exemption because

the expression "by reason of religious training and belief" is plain language, 
The Supreme Court declined to hear the Berman case, ${ }^{15}$ leaving the circuits in conflict. Congress, however, in its 1948 revision of the draft laws, defined "religious training and belief" as "an individual's belief in relation to a Supreme Being ..." ${ }^{16}$ and continued its definition of the phrase in language which implicitly endorsed the Berman decision. ${ }^{17}$ The report of the Senate Armed Services Committee made it clear that such an endorsement was intended, ${ }^{18}$ and it appeared from subsequent Ninth and Second Circuit decisions that the 1948 Act had resolved their conflict. ${ }^{19}$ As the Supreme Court denied certiorari in the Ninth Circuit

and was written into the statute for the specific purpose of distinguishing between a conscientious social belief, or a sincere devotion to a high moralistic philosophy, and one based upon an individual's belief in his responsibility to an authority higher and beyond any worldly one.

There are those who have a philosophy of life, and who live up to it. There is evidence that this is so in regard to appellant. Howvever, no matter how pure and admirable his standard may be, and no matter how devotedly he adheres to it, his philosophy and morals and social policy without the concept of deity cannot be said to be rehigion ....

Id. at $\mathbf{3 8 0 - 8 1 \text { . }}$

15329 U.S. 795 (1946).

16 Universal Military Training and Service Act, 50 U.S.C. App. $\$ 456(j)$ (1964).

17 Rehgious Training and belief in this connection means an individual's belief in relation to a Supreme Being involving duties superior to those arising from any human relation, but does not include essentially political, sociological or philoId. sophical views or a merely personal moral code.

18 This section reenacts substantially the same provisions as were found in subsection $5(\mathrm{~g})$ of the 1940 act. Exemption extends to anyone who, because of religious training and belief in his relation to a Supreme Being, is conscientiously opposed to combatant military service or to both combatant and noncombatant military service. (See United States v. Berman, 156 F.(2d) 377, certiorari denied, 329 U.S. 796 [sic].)

S. Rep. No. 1268, 80th Cong., 2d Sess. 14 (1948).

19 In George v. United States, 196 F.2d 445 (9th Cir.), cert. denied, 344 U.S. 843 (1952), the Ninth Circuit went somewhat beyond the grounds immediately necessary to its decision to discuss Congress' meaning. Since George's opposition derived from a belief in God, the permissibility of distinguishing between believers and nonbelievers was not in issue. The court nevertheless stated that the Suprene Being clause reflected the notion of "Religion" as it has commonly and traditionally been understood in this country, id. at 451 , and declared that a classification based on that understanding "would meet all the accepted tests of due process." Id. at 452 . In a later case directly challenging the constitutionality of such a classification, the court found its decision in George controlling. Clark v. United States, 236 F.2d 13 (9th Cir.), cert. denied, 352 U.S. 882 (1956).

It appeared that the Second Circuit had fallen into line in United States v. Bendik, 220 F.2d 249 (2d Cir. 1955), where the distinction between religious and nonreligious believers (or theists and nontheists) was upheld on the grounds that the exemption was a matter of legislative grace and could be conditioned as Congress saw fit. 
cases, ${ }^{20}$ that court's construction of Congress' definition of "religion" in the context of conscientious objector exentptions seemed to be established beyond challenge.

Despite this state of outward calm, tensions between the points of view described above remained unresolved. There was no split between the Ninth Circuit and Congress, on one hand, and the Second Circuit, on the other, about the basic premise underlying conscientious objection: the objection must derive from a sphere higher than the authority which issues commands of the state-in the language of Berman, from "an authority higher and beyond any worldly one." 21 To Congress and the Ninth Circuit, "higher and beyond" meant a vertical relationship with the source of one's belief- "the concept of deity." 22 This vertical relationship is the traditional American understanding of "religion" and, consequently, of "religious training and belief." ${ }_{23}$ It is also the principle of conscientious objection in a nutshell. Where state power and individual belief collide in the same sphere, the state prevails, but where individual belief derives from allegiance to the will of God, the spheres are not the same and, conceptually, there is no collision. ${ }^{24}$ This conceptualization was the premise of the Ninth Circuit in Berman and of Congress in enacting the 1948 draft law. ${ }^{25}$ Without requiring affirmation of such a vertical relationship from the objector, continues the argument, it is not only administratively difficult to filter out "merely personal moral codes," but also, by the traditional Ameri-

20 See note 19 supra.

21 Berman v. United States, 156 F.2d 377, 380 (9th Cir. 1946).

22 Id. at 380-81.

23 See note 19 supra.

24 See United States v. Macintosh, 283 U.S. 605, 627 (1931), where Chief Justice Hughes, in a famous dissent, stated:

When one's behef collides with the power of the State, the latter is supreme within its sphere and submission or punishment follows. But, in the forum of conscience, duty to a moral power higher than the State has always been maintained. The reservation of that supreme obligation, as a matter of principle, would unquestionably be made by many of our conscientious and law-abiding citizens. .. . One cannot speak of religious liberty, with proper appreciation of its essential and historic significance, without assuming the existence of a belief in supreme allegiance to the will of God.

Id. at 633-34.

25 Herman Berman's petition for certiorari, which was denied, characterized the Macintosh dissent as "naive anthropomorphism in religion based upon a two-story universe theory." Brief for Petitioner at 23, Berman v. United States, 329 U.S. 795 (1946), quoted in Conklin, supra note 2, at 273 (1963). Regarding Congress' expression of the vertical relationship premise through the "Supreme Being" requirement, see note 17 supra. 
can understanding of rehioion, any system of belief to which such affirmation is irrelevant is a "merely personal moral code." ${ }^{26}$

In Kauten Judge Hand similarly sought an authority "higher and beyond," but in a sense neither spatial nor traditional. He took into account "the characteristics of a skeptical generation" according to which "a response of the individual to an inward mentor, call it conscience or God," may be "for many persons at the present time the equivalent of what has always been thought a religious impulse." ${ }^{27}$ The issue initially creating the tension between the circuits, then, was whether objection to participation in war proceeding from "an inward mentor" could be said to be founded on "religious training and behef." If the answer were no, there would be no further problem. If the answer were yes, a further problem would be whether the Supreme Being clause limited the exemption to objections stemming from externally compelled beliefs, to the exclusion of ones internally derived. If the clause did not compel such a distinction, inquiry and tension would end. If such a distinction were compelled, however, it would then be necessary to determine whether the distinction was constitutionally permissible.

\section{Presentation of the Conflict: United States v. Seeger}

In 1964 the Second Circuit decided United States v. Seeger and declared the 1948 Act unconstitutional. ${ }^{28}$ Daniel Seeger based his opposịtion to participation in war on beliefs internally derived rather than externally compelled. He described those beliefs, in part, as follows:

Personally, I do not believe that life derives any meaning from cosmic design but I do believe that a person can give his life meaning by doing something worthwhile with it, i.e. by relating his existence in a constructive and compassionate way to the problems of his social environment. In this sense pacifism, among other things, is for me a transcendent concern and it is in this respect that I consider myself religious. ${ }^{29}$

26 See United States v. Seeger, 326 F.2d 846, 853 (2d Cir. 1964) (the government's argument), aff'd, 380 U.S. 163 (1965).

27 United States v. Kauten, 133 F.2d 703, 708 (2d Cir. 1943). Compare Judge Hand's "call it conscience or God" language with Stone, The Conscientious Objector, 21 Conum. U.Q. 253 (1919), where mere "conscience" and "religious experience" are distinguished, $i d$. at 263 , and then treated interchangeably. $I d$. at 269.

28326 F.2d 846 (2d Cir. 1964).

29 Record at 99, United States v. Seeger, 380 U.S. 163 (1965) (emphasis added). Seeger also writes, id. at 93, that "action taken through fear of God or desire for eternal reward is not moral conduct but merely expediency." This strikes at the literally fundamental notion of the traditional view that the surest guaranty of the 
The sincerity of Seeger's creed and its derivation from "religious training and belief" within the meaning of Kauten were not contested. The Government argued, however, that his claim fell outside the coverage of the 1948 statute because it was not founded "on a belief in a Supreme Being." 30

Faced with these facts, the court wrote an opinion which pervasively explored the constitutional issues surrounding conscientious objection. It first noted that whether or not Congress was constitutionally compelled to grant an exemption to conscientious objectors, no legislative power existed to place unconstitutional conditions upon the conferral. ${ }^{31}$ Having arrived at the question of the statute's constitutionality, the court proceeded to place the issue in a first amendment framework. The Government, reasoned the court, based its argument for the statute's validity upon Supreme Court interpretations of the relationship between the establishment and free exercise clauses. ${ }^{32}$ The high Court's definition construed the establishment clause to compel neutrality but not adversity towards religion..$^{33}$ Avoiding adversity, continued the Second Circuit, was necessary to escape conflict with the free exercise clause by "treading upon the individual citizen's right ..." to practice his rehigion. ${ }^{34}$ Viewed in the context of this first amendment tension, the Government's argument amounted to an assertion that the 1948 Act had merely created the greatest possible latitude for the free exercise of rehigion through conscientious objection. ${ }^{35}$

conscientiousness of a believer's pacifism is his fear of retribution by a vengeful Supreme Being, with whom the believer stands in a vertical relationship.

30 United States v. Seeger, 326 F.2d 846, 848 (2d Cir. 1964).

31 Id. at 851.

32 Id. at 851-52.

33 See, e.g., Zorach v. Clausen, 343 U.S. 306 (1952); Everson v. Board of Educ., 330 U.S. 1 (1946). In Everson Justice Black stated:

The "establishment of religion" clause of the First Amendment means at least this: Neither a state nor the Federal Government can set up a church. Neither can pass laws which aid one rehigion, aid all religions, or prefer one religion over another.

Id. at 15. That case involved use of public tax money to transport school children, including parochial school students. That use was permitted on the grounds that while it might violate the establishment clause to allow the tax, to exclude behevers from its benefits because of their faith would "hamper" them in the free exercise of their religion. A distinction among religions would, under that view, violate the establishment clause, and to deny Seeger a conscientious objector exemption because of his lack of a behief in a Supreme Being would be repugnant to the free exercise clause.

34 United States v. Seeger, 326 F.2d 846, 852 (2d Cir. 1964); see School Dist. of Abington v. Schempp, 374 U.S. 203, 247 (1963) (concurring opimion of Brennan, J.).

35 United States v. Seeger, 326 F.2d 846, 852 (2d Cir. 1964). 
The Second Circuit then found a basic fallacy in the Government's conception of the statute. If a statute's purpose is to protect the free exercise of religion, it must protect the free exercise of all religions, avoiding discrimination in this peculiarly sensitive area. ${ }^{36}$ The 1948 Act defined "religion" as belief in a Supreme Being; precedent compelled concluding that such a definition could not "embrace all those faiths which can validly claim to be called 'religious.' " ${ }^{37}$ Thus the statute only protected the free exercise of a few chosen religions and therefore constituted a discriminatory classification violative of the due process clause of the fifth amendment. ${ }^{38}$

Seeger and the 1948 Act reached the Supreme Court in consolidation with two other cases. ${ }^{39}$ In light of the Second Circuit's opinion and its

$36 I d$.

37 Id. See Torcaso v. Watkins, 367 U.S. 488 (1961). Torcaso involved a provision of the Maryland constiturion which disqualified from public office anyone who would not affirm his belief in the existence of God. Torcaso refused and was demed a notary public's commission. The Court struck down the state requirement in an opirion by Justice Black which stated that neither the federal nor the state governments "can aid those religions based on a behief in the existence of God as against those religions founded on different beliefs." Id. at 495. In a footnote Justice Black listed "Buddhism, Taoism, Ethical Culture, Secular Humanism and others" as sects which did not teach a belief in a Supreme Being but were nevertheless patently religious. $I d$. at 495 n.11.

This holding was taken by some commentators to invalidate, by implication, the Supreme Being clause of section $456(j)$ as an establishment of theistic religion. See, e.g., Conklin, supra note 2; Donnici, Governmental Encouragement of Religious Ideology: $A$ Study of the Current Conscientious Objector Exemption from Military Service, $13 \mathrm{~J}$. Pub. L. 16 (1964). Father Conklin beheved that Torcaso compelled extension of the exemption to nontheistic believers, but that this would do such violence to traditional notions of "religion" that Congress might well repeal the exemption altogether.

38 Umited States v. Seeger, 326 F.2d 846, 854 (2d Cir. 1964).

39 In United States v. Jakobson, 325 F.2d 409 (2d Cir. 1963), the defendant could not affirm a belief in a Supreme Being as such, but rather in a concept of "Godness" which

could take one or the other of two forms, a "vertical" relationship in which man relates directly to Godness, or a "horizontal" one in which man relates to Godness indirectly by binding himself to the qualities of Godness that exist in every creation in Mankind and throughout the world.

Id. at 412. The court dismissed Jakobson's indictment for refusal to submit to induction in a decision whose reasoning reflected that of Kauten, twenty years earher; the possibility that Congress might have added the Supreme Being language to narrow the scope of the exemption under the 1948 Act was simply disregarded.

Peter v. Umited States, 324 F.2d 173 (9th Cir. 1963) was the third case resolved by the Supreme Court in Seeger. The Ninth Circuit had apphed the Supreme Being clause literally in denying the exemption to Forest Peter, who, like Jacobson, was more of a traditional theist than Daniel Seeger and clearly would have been treated like Seeger had his case been decided in the Second Circuit. The three decisions, taken. together, presented the full spectrum of possible dispositions of the Supreme Being 
background of case law and legislative history, it is startling that Justice Clark's opinion for a unanimous Court read "Supreme Being" as a gloss on "religious training and belief" rather than a limitation on it, thereby bringing Damiel Seeger within the scope of the exemption by statutory construction. It is even more startling that, to judge from Justice Clark's words, the Constitution did not figure at all in the Justices' minds as they reaclied a decision.

The Court's inquiry focused upon the meaning of "Supreme Being," the stated alternatives being either "the orthodox God . . . , or a faith, 'to which all else is subordinate or upon which all else is ultimately dependent." "40 The existence of over 250 sects in this country was taken to show "the care that Congress realized was necessary in the fashioning of an exemption which would be in keeping with its long-established policy of not picking and choosing among religions." 41 This passage hints at the approach to be taken, an approach which becomes more artful at each turning. Justice Clark found ${ }^{42}$ that Congress took the Supreme Being language from its priniary source, Chief Justice Hughes' dissent in United States v. Macintosh, ${ }^{43}$ where the Chief Justice stated that "[o]ne cannot speak of religious liberty with proper appreciation of its essential and historic significance, without assuming the existence of a belief in supreme allegiance to the will of God." ${ }^{44}$ Consequently, the substitution of "Supreme Being" for "God" in the 1948 Act was interpreted by Justice Clark as a deliberate broadening of the definition, with Congress' failure to elaborate "on the form or nature of this higher authority" showing that it was mindful of Chief Justice

clause. In Peter it was held valid on its face, in Jakobson valid as construed, and in Seeger invalid however construed.

40 United States v. Seeger, 380 U.S. 163, 174 (1965).

41 Id. at 175.

42 Id.

43283 U.S. 605 (1931). The Naturalization Act of 1906, ch. 3592, \$4, 34 Stat. 596; 598, required apphicants for citizenship to swear to "support and defend the Constitution and laws of the United States against all enemies, foreign and domestic, and bear true faith and allegiance to the same." Macintosh qualified this oath by declaring that his primary allegiance was to God, and that he could go to war in defense of the United States only if the war were morally justifiable in terms of God's will. The Court held this was not the meaning Congress intended the oath to have, adding that

unqualified allegiance to the Nation and submission and obedience to the laws of the land, as well those made for war as those made for peace, are not inconsistent with the will of God.

283 U.S. at 625.

44283 U.S. 627, 634 (1931) (Hughes, C.J., dissenting). Justices Holmes and Brandeis joined the Chief Justice in dissent. 
Hughes "when he said in the same opinion that even the word 'God' had myriad meamings for men of faith." ${ }^{45}$ Since the Senate report on the bill stated specifically that section $6(\mathrm{j})$ was intended substantially to reenact the provisions of the 1940 Act, and since that Act referred only to "rehgious training and behef," the Seeger court found that "that is all that is required here." "46 The clear effect of the Court's return to the 1940 Act was to read "Supreme Being" out of the statute, and this conclusion is reinforced by Justice Clark's definition of "religious training and belief":

[A]ll sincere religious beliefs which are based upon a power or being, or upon a faith, to which all else is subordinate or upon which all else is ultimately dependent. The test might be stated in these words: A sincere and meaningful belief which occupies in the life of its possessor a place parallel to that filled by the God of those admittedly qualifying for the exemption comes within the statutory definition. ${ }^{47}$

Suggesting the Court's reason for such a tortured interpretation of the statute, Justice Clark added that "this construction avoids imputing to Congress an intent to classify different religious beliefs, exempting some and excluding others. ..." 48 The meaning of this phrase is plain. If "religious training and belief" were construed to say what Congress, through the "Supreme Being" gloss, intended it to mean, and what the Government urged upon the Court in this case, there would have been no room for a judicial definition under the guise of statutory interpretation. The Court would have been obliged to abide by Congress' defini-

45 United States v. Seeger, 380 U.S. 163, 175-76 (1965).

46 Id. at 176.

47 Id. A phrase of similarily dark ambiguity appears in the Court's explanation of how it came about that neither the Supreme Being clause nor the citation to Berman at the end of it in the Senate report, see note 18 supra, implied an adoption of the holding in that case. The Court said that "[s]uch a claim will not bear scrutiny. ... [W] think it clear that an explicit statement of congressional intent deserves more weight than the parenthetical citation of a case which might stand for a number of things." 380 U.S. at 177. The opinion goes on to declare that "Congress' action in citing it must be construed in such a way as to make it consistent with its express statement that it meant substantially to re-enact the 1940 provision." Id. at 178 (emphasis added).

Having decided what "muste" be done, Justice Clark proceeded to do it, by finding that in both Kauten and Berman political, social and moral views were held beyond the ambit of the exemption, which was denied in both cases on that ground; therefore, and because certiorari was denied in Berman, "we think that rather than citing Berman for what it said 'religious belief' was, Congress cited it for what it said 'religious belief' was not." Id. at 178-79.

48 Id. at 176. 
tion or strike it down on constitutional grounds in order to substitute one of its own. The transparency of the fiction that Seeger is merely a matter of interpreting the statute is tacitly admitted in Justice Douglas' concurring opinion. Stating the consequences of a statutory construction other than that developed by the Court, he observes that

then those who embraced one religious faith rather than another would be subject to penalties; and that kind of discrimination, as we held in Sherbert $v$. Verner, 374 U. S. 398, would violate the Free Exercise Clause of the First Amendment. It would also result in a denial of equal protection by preferring some religions over others-an invidious discrimination that would run afoul of the Due Process Clause of the Fifth Amendment. See Bolling v. Sharpe, 347 U.S. 497.

... [I $] \mathrm{t}$ is, in my opinion, not a tour de force if we construe the words "Supreme Being" to include the cosmos, as well as an anthropomorphic entity. If it is a tour de force so to hold, it is no more so than other instances where we have gone to extremes to construe an Act of Congress to save it from demise on constitutional grounds. In a more extreme case than the present one we said that the words of a statute may be strained "in the candid service of avoiding a serious constitutional doubt." United States v. Rumely, 345 U.S. 41, 47.49

\section{The "Rule" of Seeger}

The constitutional underpinnings of Seeger are sufficiently apparent, even without Justice Douglas' implied threats, to justify treating the rule it promulgates as the minimum permissible scope of the conscientious objector exemption. ${ }^{50}$ Although the Court would probably balk

$49 \mathrm{Id}$. at 188. The brief submitted for Jakobson, who had profited in the court below from such a "straining" of the words of this statute, urged

In accordance with the established rule, every effort should be made to construe the statutory language in the candid service of avoiding a serious constitutional doubt.' United States $v$. Rumly [sic], 345 U.S. 42, 47. Brief for Jakobson, No. 51, at 21, United States v. Seeger, 380 U.S. 163 (1965).

50 The 1967 amendment to the statute, 50 U.S.C. APP. $\$ 456(j)$ (1967), omits the Supreme Being language, but this revision does not necessarily indicate congressional acquiescence in Seeger. The House report states only that

... the committee language requires that the claim for conscientious objection be based on "rehigious training and belief" as has been the original intent of Congress in drafting this provision of the law.

H.R. Rep. No. 267, 90th Cong., 2d Sess. 31 (1967). It is stated in the Conference Report that "the Senate conferees also concurred in the desire of the House language to more narrowly construe the basis for classifying registrants as 'conscientious objectors." Conf. Rep. No. 346, at 9 (1967). 
if Seeger were urged upon it as binding constitutional precedent, the case does afford a sound basis from which to extrapolate the principles the Court would apply should other cases come before it on unavoidably constitutional grounds.

The Court excludes from the exemption only persons who "disavow rehious belief" and base their opposition to participation in war on "essentially political, sociological or economic considerations" or on a "merely personal moral code." ${ }^{51}$ The problem, however, is to ascertain what it is that an objector must show in the matrix of his beliefs for them to be considered religious.

The Court's opinion leads one to the conclusion that a concept of ultimate dependence or subordination is in fact the basis of the Seeger rnle. ${ }^{52}$ Justice Clark, contemplating Damiel Seeger's exemplary personal qualities and dedication to social welfare, was "reminded" of the following quotation from Tillich:

And if that word [God] has not much meaning for you, translate it, and speak of the depths of your life, of the source of your being, of your ultimate concern, of what you take seriously without any reservation. 53

Earlier in the opinion, another quotation from Tillich was offered to illustrate the all-encompassing scope of the offered test:

The source of . . . affirmation of meaning within meaninglessness, of certitude within doubt, is not the God of traditional theism but the

51 United States v. Seeger, 380 U.S. 163, 173 (1965). It is not clear if this "disavowal" must be affirmative or, if so, how irrehgion can be proved against one who claims to be religious.

52 The Court's expression of its test as requiring that the claimed behef occupy "a place in the hife of its possessor parallel to that filled by the orthodox belief in God of one who clearly qualifies for the exemption," id. at 166, is not helpful. It may be more illuminating to take the dictionary definition of theism quoted by Justice Clark: "Does the term 'Supreme Being' as used in $\$ 6(\mathrm{j})$ mean the orthodox God or the broader concept of a power or being, or a faith, "to which all else is subordinate or upon which all else is ultimately dependent'?", $i d$. at 174, as indicative of what the Court had in mind. That definition identifies the principle from which orthodox beliefs and moral codes not "merely personal" both derive; it is a sounder starting point for discussion than the Court's "God or equivalent" language, which appears to contemplate a Cinderella test by which a claimant to religious status must squeeze his foot into the shoe of one whose status is already recognized.

53 P. Thlich, The Shaking of the Foundation 57 (1948), quoted in 380 U.S. at 187 (emphasis added by the Court). 
"God above God," the power of being, which works through those who have no name for it, not even the name God. ${ }^{5 *}$

The Court, then, construed belief in a "Supreme Being" to mean theism, and theism to mean a belief, however inarticulate, which refers to an ultimate concern.

If "ultimateness" is a subjective notion, varying infinitely according to the preoccupations of different people, it can be argued that the Court, in its effort to remedy the present statute's vulnerability to constitutional attack, not only brought all "religion" within the scope of the exemption but in effect eliminated "religion" as a consideration altogether. Assuming that the "God above God" of Tillich, endorsed by the Court, does work through everyone, its manifestation in any particular person will be discovered in that which he takes "seriously without any reservation." The Court's articulation of this standard suggests that anyone who takes sometbing "seriously without any reservation" could qualify for the exemption if that "something" compels pacifism. Furthermore, it can be argued that everyone has some such nltimate concern; if that were all Seeger required, the Pope, Mao-tse Tung and Ayn Rand would all qualify as religious, if not pacifist. Conceivably a man whose sincere and ultimate concern was his bank account could avoid military service if he would lose income by performing it. If the Seeger rule could not be invoked to exclude such a registrant, the test would be completely subjective and religion would be immaterial to eligibility for the exemption. Under this interpretation the selective objector with genuinely religious motivation would be deprived of a first amendment basis for attacking his exclusion from exemption-a substantial deprivation, as the first amendment is the strongest basis for any judicial attempt to broaden the scope of the exemption as it now stands or to compel its retention in the event Congress should decide to withdraw it. If religion had been read out of the statute, it would be difficult for the religious objector to attack it as denying him due process or as abridging the free exercise of his religion.

Clearly the Court did not intend such a result, and these implications may not correctly be read into Justice Clark's opinion. ${ }^{55}$ The Court's

\footnotetext{
54 P. Thlich, II Systematic Theology 12 (1957), quoted in 380 U.S. at 180.

55 It has been asserted that

The Court's definition of theists is so broad that the only persons who might be called atheists are nihilists and those who have not considered the nueaning of life sufficiently to have a belief regarding its meaning.

Note, Defining Religion: Of God, The Constitution and the D.A.R., 32 U. CHI. L. REv. 533, 552 (1965). The probable truth of this remark tends to support, rather than refute, the proposition that Seeger did not read religion out of the statute.
} 
equation of religious belief with "ultimate concern" must be read together with its affirmation of the statutory refusal to allow the exemption on the basis of "essentially political, sociological or economic considerations" or a "merely personal moral code." 56 In its references to. Tillich's theology, the Court obviously intends to establish a test which is not satisfied merely by the subjective importance to an individual of any given concern, but which requires a certain philosophical depth in the concern itself, though the nature of this kind of concern may defy exact description. As Professor Mansfield has pointed out:

Religion cannot be satisfactorily defined merely by reference to the role that a belief plays in the life of the believer. To some extent the idea of religion depends on the nature of the questions to which the belief provides an answer and the fundamental character of the realities that the believer asserts. 57

Even though the Court was unable to articulate precisely the standard by whiclı ultimateness can be measured, some claims will fail under the Seeger test simply because the shallow character of the beliefs on which they are based will not permit holding them compelled "by reason of religious training or belief." ${ }^{58}$ Thus, the Court is not inaccurate

56 United States v. Seeger, 380 U.S. 163, 173 (1965).

57 Mansfield, Conscientious Objection-1964 Term, 1965 Reuigion \& Public Order 1, 33-34. Cf. Rabin, When Is a Religions Belief Religious: United States v. Seeger and the Scope of Free Exercise, 51 ConNell L.Q. 231, 249 (1966), where the author states:

Seeger offers a necessary guarantee that the individual's system of belief will be subjected to no value-oriented order of priorities vis-a-vis other systems of belief. The fact that this viewpoint may be foreign to the "religious" notions of the founding fathers is irrelevant to a liberal view of the principle which they established: that every man's moral conceprualization of existential phenomena is entitled to the same respect from state authority.

Seeger does not guarantee, however, that a man can command that respect from state authority without actually having made some such "moral conceptualization of existential phenomena." Cf. note 55 supra.

58 See United States v. Seeger, 326 F.2d 846, 852-53 (2d Cir. 1964). This reading of Seeger, here suggested as preferable in logic as well as result, was anticipatorily damned by one commentator in the following terms:

Since any attempt by a court to define or interpret the word "religion" in the first amendment must, of necessity, imply the exclusion of some opinions which a small minority may choose to call religion, the plain implication ... is that any such attempt is automatically unconstitutional. . . Any [legislative] definition would have to include all who "believe", even if that be a "non-belief." Conklin, supra note 2 , at 277 .

Seeger appears to modify the effect of United States v. Ballard, 322 U. S. 78 (1944), at least where section $456(j)$ is concerned. To Ballard's holding that the truth or falsity of religious views is not a matter into whicb a court can inquire, Seeger adds the gloss 
in characterizing its test as "objective;" 59 indeed, the whole purpose and function of the "ultimateness" test in the Court's opinion is to establish an objective rather than subjective standard by which objector claims may be judged. It would violate the sense as well as the intent of the rule to maintain that the mundane consequences of a belief (i.e., objection to war) must be respected when the considerations on which the belief is ultimately dependent are mundane as well.

In formulating an "ultimate concern" test and emphasizing that "the statute does not distinguish between externally and internally derived beliefs," 60 the Court's apparent intention is to suggest that devotion to an abstract concept which is descriptive of some human quality or relationship is sufficient to qualify a registrant for conscientious objector status. Thus, exemption should be granted to a registrant who is devoted to love, peace, justice, or similar ideals which are motivated from and find their source within the individual but, because they require for fulfillment an active commitment to the community of mankind, are not merely personal. Seeger held such a belief-a "belief in and devotion to goodness and virtue for their own sakes." 6I It is unfortunate that the substance of the Court's standard is obscured by the opinion's lip service to the statute's "Supreme Being" clause; Justice Clark takes pains to bring Seeger within the clause by noting that he did not explicitly disavow a belief in a Supreme Being, ${ }^{62}$ and emphasizing that Congress intended to exclude ouly "a moral code

that in the context of conscientious objection there may be some views which, however true they may be and no matter how sincerely held, cannot compel recognition as "rehigious."

59 United States $\nabla$. Seeger, 380 U.S. 163, 184 (1965).

60 Id. at 186.

61 Id. at 166. The Court quotes, id. at 183, a statement by a leader of the Ethical Culture Movenuent which further illuminates Seeger's kind of nontheistic idealism:

"Instead of positing a personal God, whose existence man can neither prove nor disprove, the ethical concept is founded on human experience. It is anthropocentric, not theocentric. Religion, for all the various definitions that have been given of it, must surely mean the devotion of a man to the highest ideal that he can conceive. And that ideal is a community of spirits in which the latent moral potentialities of men shall have been elicited by their reciprocal endeavors to cultivate the best in their fellow men."

D. Muzzex, Ethics As a Religion 95 (1951).

62 Justice Clark observed that Seeger "did not disavow any belief in a relation to a Supreme Being'; nudeed, he stated that 'the cosmic order does, perhaps, suggest a creative intelligence." " 380 U.S. at 187 . The Court's reliance upon this modest affirmation, a sop which a bored but polite heathen might use to pacify a doting missionary, illustrates clearly the palpably fictional character of the opinion's statutory interpretation. 
which is not only personal but which is the sole basis for the registrant's belief and is in no way related to a Supreme Being." 63 This result amounts to a rule that a scintilla of religion will suffice and, absent a considerable lack of cooperation from the registrant, a scintilla will be found. ${ }^{64}$

The elements of the Seeger test are not difficult to express, however burdensome they may be to apply. The only questions open for the local draft board are:

1. Is the registrant sincere in his asserted opposition to participation in war in any form? ${ }^{65}$

2. Is that opposition essential to his asserted religious faith?

3. Is the faith he asserts derived from belief in something upon which all else is ultimately dependent?

Upon examination, the test turns out to repeat faithfully all the principles of the conscientious objector provisions of the past. But Seeger departs from prior congressional formulations of those principles, for it finally abolished any vestige of a requirement of affirmation of belief in an anthropomorphic deity.

This restriction was arguably important as a check on the abuse of the exemption, and may have been helpful in administering the draft system. It was clearly regarded by the Court as a distinction among faiths in terms of their source, prejudicial to those internally derived. It

63 United States v. Seeger, 380 U.S. 163, 186 (1965) (emphasis added).

64 Although Justice Clark declared that no question of atheism was presented in Seeger, id. at 173-74, it has been suggested that

if petitioner were an "atheist" quite the same problems would exist and, in fact, the answers have been settled by Seeger. The term "atheist" which is in itself hopelessly vague, is totally irrelevant after Seeger.

Rabin, supra note 57 , at $242-43$. If this conclusion is correct, it is so for reasons somewhat different from those which seem to underhe the quoted comment. Anyone who can actually be called an "atheist" must have grappled considerably with "existential phenomena" or the meaning of life in order to reach such a position; the test of "ultimateness" would probably be satisfied by the views of such a person. However, it is hard to imagine how views so derived could compel opposition to participation in war.

It bears emphasis that the above-discussed implications of the Court's standard in Seeger are much more compelling in legal theory than in actual practice at the local board level. For description of the gap between theory and practice in the operation of the Selective Service System, see notes 97-98 infra and accompanying text.

$65 \mathrm{See} 380$ U.S. at 185. The Court refers to the facilities of the Department of Justice as an aid to local boards in determining sincerity. Under the 1967 amendment to the Selective Service Act, those facilities are no longer available. 50 U.S.C. ApP. $5456(j)$ (1967).

66 See 380 U.S. at $184,186$. 
denied to some an exemption to which the demands of their conscience entitled them, solely for their failure to fall within the arbitrary class of traditionally recognized theists. However acceptable such a classification might be in terms of the convemience and conventional wisdom of the political majority, the Court condemned it, by implication too strong lonestly to be ignored, as a denial of due process of law. If the exemption is extended to persons opposed to war by reason of rehgious training and belief, then it must be open to all persons who oppose war by such reason.

The only substantial qualification still imposed on otherwise ehigible religious objectors is that opposition must be to participation in "war in any form." That restriction was not at issue in Seeger, but the decision does suggest the considerations which might weigh most heavily with the Court if it were faced with an attack on the restriction.

\section{"War In ANY Form"}

The phrase "war in any form" first appeared among the statutory criteria for conscientious objector exemptions in the Selective Draft Act of 1917.67 That Act was more restrictive than any other, before or since; it confined the exemption to members of "any well-recognized religious sect or organization ... whose existing creed or principles forbid its members to participate in war in any form ...." ${ }^{68}$ The vulnerability of the 1917 statute to constitutional attack under present doctrines is evident, for the requirement of "peace church" affiliation patently "constituted a severe restriction of the free exercise of religion." "The same can be said of the requirement of complete pacifism, whether it is sought to be justified as a test of sincerity, as a device to facilitate administration of the Selective Service System, or as a legislative judgment that only complete pacifism can be grounded in religious training and belief.

No objection is reported to the retention of the "war in any form" language in the 1940 Act. $^{70}$ The requirement ironically received its most influential support from Judge Hand's celebrated dictum in United States $v$. Kauten ${ }^{71}$ which paved the way for including within the scope of the exemption persons whose religious views were internally

67 See text at notes 5-6 supra.

68 Act of May 18, 1917, ch. 15, 40 Stat. 76 (1917).

69 Conklin, supra note 2 , at 261.

70 See notes 8,9 supra.

71133 F.2d 703 (2d Cir. 1943). See note 11 supra. 
derived. It is not clear whether Judge Hand was expressing a personal conviction or merely yielding all ground not necessary to the point he needed to make when he stated:

There is a distinction between a course of reasoning resulting in a conviction that a particular war is inexpedient or disastrous and a conscientious objection to participation in any war under any circumstances. The latter, and not the former, may be the basis of exemption under the Act. The former is usually a political objection $\ldots .^{72}$

The first hurdle for a selective objector, therefore, is to demonstrate that objection to a particular war can in fact be based on religious training and belief. The Court could not juggle the present statute so as to include non-pacifist objectors without engaging in the sort of legerdemain employed in Seeger, and it is fair to suppose that the Court would not do so absent a clear showing, present in Seeger, that only by so doing could the constitutionality of the statute be preserved. It would not suffice to show that nonpacifist objection may be consistent with the statute; a right must be shown which the statute must be construed to vindicate. The first teaching of Seeger is that if such a right can be shown, the Court is quite capable of making the statute conform to it.

\section{The Just War Doctrine: Religion and Selective Objection}

Judge Hand's dictum assumes rather than proves that there can be no constitutional protection for selective objection when he speaks of "a course of reasoning resulting in a conviction that a particular war

72 Id. at 708. Some comfort, in terms of the philosophy of Seeger, can be gleaned from the word "usually." It has, however, gone generally unnoticed, perhaps on the theory that when the bath is big and the baby small, they both may be pitched out together. The view of the Marshall Commission in its 1967 report of the draft was virtually identical to Judge Hand's, although a contrary minority opinion was presented and appears in the report as well. The majority, in refusing to recommend deletion of the complete pacifism restriction, declared its belief

that the status of conscientious objection can properly be applied only to those who are opposed to all killing of human beings under any circumstances. . . .

[T] he majority loolds that so-called selective pacifism is essentially a political question of support or non-support of a war and cannot be judged in terms of special moral imperatives.

Report of the National Commission on Selective Service, In Pursutr of Equtry: Who Serves When Not Alt Serve? 50 (1967) (hereinafter cited as Marshatl ComMISSION Report). The minority view, $i d$. at $48-50$, provides a good summary of the arguments in favor of allowing selective objection. 
is inexpedient or disastrous . . ." "73 Clearly "reasoning" as to what may be "inexpedient or disastrous" is not a process imbued with religious values and, to the extent that an objection to a particular war can be arrived at in only that way, Judge Hand is quite correct in his conclusion.

From the traditional and quite orthodox Christian viewpoint, however, such a position can be compelled by one's faith as well as one's reason. The "Just War" doctrine, derived in part from the writings of Augustine $^{74}$ and Aquinas, ${ }^{75}$ provides the Christian with "an explicit basis for discrimination between justifiable and unjustifiable uses of force." 76

The Just War doctrine is recognized by most orthodox Christian denominations and can hardly be considered a novel theological concept. ${ }^{77}$ It is, however, always a surprise to be reminded that a good Christian, in theory at least, regards all wars as unjust and participates in some of them only as far as the doctrine permits him to make exceptions. ${ }^{78}$ The Selective Service System included in one of its mono-

73 United States v. Kauten, 133 F.2d 703, 708 (2d Cir. 1943).

74 Sr. Augustine, City of God XIX, vii.

75 T. Aquinas, Summa Theologiae, First Part of the Second Part, question 105(3).

76 Potter, supra note 11, at 69. Dr. Potter describes application of the Just War doctrine as "a complex process of reasoning, combining fundamental theological beliefs, theologically derived ethical norms, convictions concerning ultimate loyalties, and specific empirical input," id. at 67 , and asks "[d]oes the presence of nontheological elements, especially the necessary incorporation of factual information concerning specific political and military events, disqualify an objection based on such reasoning as being not grounded strictly in 'religious training and belief?'" Id. at 69 . His answer is that "the norms of the Just War are instilled by, and receive their potency from, 'religious training and belief." Id. at 70; cf. note 86 infra and accompanying text.

77 Id. at 66-70. See also R. Tucker, ThE Just WAR: A StudY IN Contemporary AMERICAN Doctrine (1960).

78 In E. Long, War and Conscience in America (1968) it is noted that Augustine himself urged strict obedience to the state as a Christian duty, even where the state's commands are unjust. The present understanding of the Just War doctrine derives from the interpretation given it by Francisco de Vitoria, a sixteenth-century Dominican theologian. De Vitoria maintained that the prince's command does not reheve the individual from his duty to act according to his conscience, and that no man may fight in a war he himself believes unjust. Id at 32. This interpretation has been endorsed recently by the Fourth Assembly of the World Council of Churches. N.Y. Times, July 17, 1968, at I, col. 3. The World Council's statement declares in part that

[p]rotection of conscience demands that the churches should give spiritual care and support not only to those serving in armed forces but also to those who, especially in the light of the nature of modern warfare, object to participation in particular wars they feel bound in conscience to oppose.

Id. at 10 , col. 1 . 
graphs the statement that "from the time of Constantine ... Christianity generally accepted the theory of 'the just war.' " 79 To assure a Christian registrant that some wars are just could well be to remind him that other wars may not be. Unless one is prepared to endorse the theology of Justice Sutherland in Macintosh that as a matter of law a war declared by Congress is consistent with the will of God, ${ }^{80}$ the existence of a recognized, if neglected, ${ }^{81}$ orthodox religious doctrine reserving the right of distinction to the individual believer defeats the conventional, unexamined assumption that objection to a particular war is a fortiori a political stance. ${ }^{82}$

The selective objector's real difficulty in gaining acceptance of his position is clarifying the "religiousness" of the context in which his judgments may be made. While Daniel Seeger did not think about the policies of a particular war because he was against all war, the selective objector is required to consider political facts in reaching his decision. A "just war" is one which meets all of a number of requirements, ${ }^{83}$ those generally agreed upon being the following:

1. All peaceful means of resolving the conflict must have been exhausted before recourse is had to war.

2. The war must be formally declared by legitimate authority.

79 Selective Service System, Spectal Monograph No. 11, 1 Conscientious Objection 8 (1950).

80 See note 43 supra.

81 Potter, supra note 76, at 74-77. The churches have neglected the doctrine, according to $\mathrm{Dr}$. Potter, because as war has come to be seen as an all-or-nothing affair, pacifism has come to be thougbt of as an all-or-nothing decision.

The shadow of the nuclear bomb kept the just war doctrine in eclipse. Fine distinctions seemed "irrelevant" in a time of anticipated apocalypse. But under the nuclear umbrella lesser wars are being fought, wars in which decisions con1d. at 75-76.

cerning permissible means bear heavily upon individuals at every rank. . . .

82 The Marshall Commission considered the Just War doctrime and decided that since it would be interpreted in different ways by different denominations it was "therefore not a matter upon which the Commission could pass judgment." Marshall Commission Report 50. It does not necessarily follow that because an admittedly religious doctrine is not uniform among sects it is therefore not religious, but the Commission's holding that "so-called selective pacifism . . . cannot be judged in terms of special moral imperatives," id., suggests it so concluded.

83 It may have been the lack of consensus as to the number of requirements which made the Marshall Commision decline seriously to consider the doctrine. E. Long, supra note 75, gives six; seven are listed in Petitioner's Brief for Certiorari, United States v. Spiro, 384 F.2d 159 (3d Cir. 1967), cert. denied, 390 U.S. 956 (1968); and a short article in THE NEw RePublic, July 1, 1967, at 15, summarizing the Augustinian formulation, lists four. The tenor and substance of the requirements are uniform, however, whether or not there is agreement on their exact number. 
3. The war must be in defense of a "morally preferable cause against threats of destruction or the rise of injustice." 84

4. There must be reasonable assurance of success.

5. There must be, in the war as a whole and with respect to any act within the war, a balance in which the good outweighs the evil.

6. The means of warfare must be legitimate: there must be no indiscriminate killing of noncombatants. ${ }^{85}$

84 E. LoNG, supra note 78 , at 24.

85 The doctrine has been raised as a defense to a prosecution for failure to submit to induction only once to date, in Unired States v. Spiro, 384 F.2d 159 (3d Cir. 1967), cert. denied, 390 U.S. 956 (1968). Stephen Spiro was a Roman Catholic who had received a I-A-O classification (noncombatant military service) from his draft board; le appealed seeking a I-O classification (civilian alternative service). After an F.B.I. investigation and a hearing by a Justice Department Hearing Officer, his file was returned to the local board with a negative recommendation, and the local board classified him I-A. A week later the board sent Spiro an induction order, but Spiro refused to submit to induction.

His defense was his adherence to the Just War doctrine as a traditional teaching of the Roman Catholic Church; apart from his attendance at a military high school, admittedly some years before he had heard of the doctrine, there appeared no reason to question his good faith in his professions, nor of his familiarity with the doctrine itself.

Spiro was not a selective objector, lowever, because he maintained that "there had never been a just war in history and there never could be." Id., Petitioner's Brief for Certiorari at 8a-9a. The fact that Spiro could theoretically participate in war, though he claimed for practical purposes to be a total pacifist, was held grounds for the local board's classification and induction order. The Third Circuit affirmed, in an unreported opinion which does not discuss Spiro's Just War doctrine claim, and the Supreme Court denied certiorari, Justices Black and Douglas dissenting.

Spiro's case is interesting less as the only judicial treatment (or non-treatment) of the Just War doctrine, or as a selective objection case, than as it relates to a line of prior cases dealing with Jehovah's Witnesses, totally inconsistent with the result in Spiro. The Jehovah's Wimesses cases are of doubtful applicability to the selective objection problem, but they have been relied on extensively in at least one case of selective objection. Noyd v. McNamara, 378 F.2d 538 (10th Cir.), cert. denied, 389 U.S. 1022 (1967). They represent one line of attack on the "war in any form" language of section $456(\mathrm{j})$.

Jehovah's Witnesses are not permitted to serve in the army of a mere political state, but they are prepared to wage a holy war for their faith, for "Kingdom interests." The Government contended in several cases that "war in any form" means what it says and Witnesses could not, therefore, meet the statutory requirement of complete pacifism. But in Taffs v. United States, 208 F.2d 329, 331 (8th Cir. 1953), cert. denied, 347 U.S. 928 (1954), it was held that

[Congress] intended by this section to exempt those persons from serving in the armed forces whose religious beliefs were opposed to any form of participarion in a flesh and blood war between nations.

Judge Medina, in United States v. Hartman, 209 F.2d 366 (2d Cir. 1954), relied on Taffs for the proposition that, since there is only one form of war, "in any form" must modify "participation," thus disposing of the Government's clain that Congress meant to include theocratic wars within the statute. Id. at 371.

The question was laid to rest by the Supreme Court in Sicurella v. United States, 
Application of these requirements to any particular war necessarily involves the weighing of political facts which the state itself has already considered. Therefore, it is not surprising that opposition to such a war derived from that application might be regarded as political rather than religious in character, and a threat to good order. Although the selective objector may have applied religious criteria to political facts, the context in which he makes his decision is not readily apparent; the practical political consequences of his decision, however, are obvious.

The fact situation in Seeger presented this kind of difficulty. The Government argued that Seeger's beliefs were too strongly tainted by reason and temporal considerations to merit consideration as "religious." ${ }^{86}$ The Court held, however, that a moral code is beyond the scope of "religious training and belief" only if it is both personal and the sole basis for the asserted belief. ${ }^{87}$ This holding applies with peculiar force to claims of selective conscientious objection. It must be granted that there is a Just War doctrine, that the doctrine is a part of the teachings of admittedly religious denominations, and that the doctrine requires believers to pass judgment on a war before participating in it.

348 U.S. 385 (1955). Sicurella stated he would fight for Kingdom interests, in support of his brethren and in defense of his property, but not in carnal wars. Justice Clark wrote for the Court that

[t] he test is not whether the registrant is opposed to all war, but whether he is opposed, on religious grounds, to participation in war. As to theocratic war, petitioner's willingness to fight on the orders of Jehovah is tempered by the fact that ... their history records no such command since Biblical times .... Id. at 390-91. Justice Minton asserted in dissent that the majority opinion left Sicurella "the right to choose the wars in which he will fight," id. at 395, and his statement has been cited as proof of the truth of its assertion.

In granting the exemption, the Court did not find that the staturory "war in any form" qualification was satisfied by a state of facts in which Jehovah inight order Sicurella to fight in some terrestrial wars but not in others. It is clear that the holding rests on the assumption that there will be no divine commands at all. The Court holds, in effect, that Jehovah and Congress wage different kinds of war. Even if it were possible, in the abstract, that their wars might be of the same sort, Congress has made several formal declarations of war in under 200 years, while Jehovah has declared none in several millennia. Therefore the Court will not take His reserved power to do so into account in deciding cases. No very compelling argument can be made for selective objection from this material, but it is quite clear that Spiro, under the Court's reasoning in Sicurella, had a better claim to the exemption than the Jehovah's Witnesses.

so The Government's argument has been characterized as betraying

a naive, fundamentalist attitude . . . toward the relation between religious truth and the formulation of moral judgments. [It seems] to suggest that if the intellect and reasoning have a hand in the matter, the conclusion reached cannot really be considered a religiously founded one.

Mansfield, supra note 57 , at 18-19.

87 United States v. Seeger, 380 U.S. 163, 186 (1965). 
It follows that if a member of one of those denominations actually does apply the doctrine to a particular war and finds he cannot participate in it, his claim as a selective objector would have a religious basis. The fact that temporal considerations figured in the decision upon which his claim is based does not negate the religious character of that decision, nor that of the opposition itself as an exercise of his religion. No matter how many political factors he may have weighed, and no matter how personal some of his judgments may have been, his asserted belief and claim do not rest solely on non-religious considerations. If this is true for a selective objector who belongs to a denomination which recognizes the Just War doctrine, it must be true as well for the selective objector whose religious scruples may be informal, individual, and recognizable only to Tillich or the Supreme Court. ${ }^{88}$

\section{Selective Objection and Equal Protection}

If two registrants claim exemption and both of them demonstrate sincerity in an opposition which represents a meamingful part of a value system fundamental in character, both of their claims, under Seeger, are based on "religious training and belief." If one of them, however, asks only for exemption from participation in a particular war, his claim will be denied under present law, while the other will be granted. If it is conceded that a selective objector may be religiously motivated, then the "in any form" statutory classification is just as discriminatory in its effect upon the selective objector's exercise of his religion as the Supreme Being requirement was upon Seeger's exercise of his nontheistic faith. If an exemption is extended to persons opposed to participation in war because of religious belief, it cannot constitutionally be denied those whose religious beliefs compel them to oppose participation in some wars only. ${ }^{89}$

If a selective objector were to attempt to force his inclusion within the existing statutory exemption, he would have to demonstrate that the classification restricting the exemption to total pacifists denies him the equal protection of the law to such an extent that it constitutes a

88 Denominational preference in granting the exemption would violate the establishment clause. See Justice Black's statement, quoted supra note 33.

89 The issue at this point is merely the constitutionally required scope of whatever exemption Congress chooses to provide, not whether any exemption is constitutionally compelled. See Speiser v. Randall, 357 U.S. 513, 518 (1958). See generally Note, Unconstitutional Conditions, 73 Harv. L. Rev. 1595 (1960). 
deprivation of his liberty without due process of law. Ordinarily the underinclusiveness of such a classification could be defended successfully by showing its rational relation to a substantial governmental interest; ${ }^{90}$ in this instance that interest would be the integrity and administrative feasibility of the Selective Service System, an interest which the Court has found to be "vital" and "substantial." 91 In the area of conscientious objection, however, the selective objector is allegedly deprived of a religious liberty by the classification. Therefore, demonstrated underinclusiveness establishes infringement not only of due process but also of the right to the free exercise of religion. The equal protection argument, then, must be fought on first amendment grounds, and the burden placed upon the Government to justify the retention of the "in any form" classification is considerably greater than it would be if religion were not involved. The extent of that burden was spelled out by the Supreme Court in Sherbert v. Verner:

It is basic that no showing merely of a rational relationship to some colorable state interest would suffice; in this highly sensitive constitutional area, "[o]nly the gravest abuses, endangering paramount interests, give occasion for permissible limitation." ... [I]t would plainly be incumbent upon the [state] to demonstrate that no alternative forms of regulation would combat such abuses without infringing First Amendment rights.92

The classification presently imposed by the "in any form" requirement has the same function as the "Supreme Being" clause construed out of the statute in Seeger. Both phrases are obviously inadequate as descriptions of religion, and were intended rather to safeguard the administrative feasibility of the Selective Service System. In Seeger the Government argued that, while to grant no exemption at all would be "calloused interference with religious liberty," ${ }^{33}$ wholesale exemption of nontheists wonld "undermine confidence in the concept of universal service." 94 The crux of the Government's argument was not that nontheists were insincere or irreligious, but that if the Supreme Being limitation were eliminated, so many people would obtain exemptions

90 See generally Tussman \& tenBroek, The Equal Protection of the Laws, 37 CaLIF.

L. Rev. 341 (1949).

91 See note 95 infra.

92374 U.S. 398, 406-07 (1963).

93 Reply Brief for the United States at 14, United States v. Seeger, 380 U.S. 163 (1965).

94 Id. at 80. 
that the concept of universal service and the conscription system itself would be undermined.

Nothing in the Seeger opinion indicates whether the Court rejected this in terroren approach because it did not believe it or because it did not greatly care about the Selective Service System. ${ }^{95}$ The Court's sedulous avoidance of any imputation to Congress of an intent to pick and choose among religions-in the face of the Government's contention that Congress felt obliged to do exactly that-suggests that, no matter how much respect the Court has for the Selective Service System, it will not permit an infringement of religious freedom to save the System without the most compelling demonstration that the System can only thus be saved. There is no reason to believe, therefore, that the requirements of Sherbert $v$. Verner are to be relaxed in a conscientious objection case.

In Seeger the Government argued in terrorem on principle alone; if

95 In United States v. O'Brien, 391 U.S. 367 (1968), the Court reversed a decision in the First Circuit that a conviction for draft-card burning under the 1965 amendment to section 462 of the draft law violated freedom of speech protected by the first amendment. Chief Justice Warren, writing for the Court, declared that even assuming arguendo that O'Brien's conduct could be brought within the scope of the first amendment, "it does not necessarily follow that the destruction of a registration certificate is constitutionally protected activity." $1 d$. at 376. The Government had contended that penalties for such destruction were required to deter actions which would substantially interfere with the administration of the Selective Service System. The Chief Justice went on to characterize the test which such an asserted state interest would have to meet to override a claim like O'Brien's, $i d$. at 377 , in terms reminiscent of Sberbert $v$. Verner, though noticeably less strong:

[W] think it clear that a government regulation is sufficiently justified if it is within the constitutional power of the Government; if it furthers an important or substantial governmental interest; if the governmental interest is unrelated to the suppression of free expression; and if the incidental restriction on alleged First Amendment freedom is no greater than is essential to the furtherance of that interest.

O'Brien's asserted constitutional right was a penumbral one, while free exercise of religion is expressly granted by the first amendment. It does not appear from the Chief Justice's opinion whether a less exiguous claim under the religion clauses of the first amendment would result in the application of more stringent criteria to an asserted countervailing government interest. Where that interest is the smooth functioning of the Selective Service System, however, the O'Brien opiuion is instructive. Finding that Congress' power to "raise and support armies and to make all laws necessary and proper to that end is broad and sweeping," $i d$. at 377 , the Chief Justice wrote that

the Nation has a vital interest in having a system for raising armies that fnnctions with maximum efficiency and is capable of easily and quickly responding to continnally changing circumstances. For these reasons, the Government has a substantial interest in assuring the continuing availability of issued Selective Id. at 381 .

Service certificates. 
it seeks to justify "in any form" on the same grounds, it will have to clothe its principle in facts sufficient to show that the terror is real. ${ }^{.96}$ It must demonstrate that "in any form" is an objective test of sincerity, the last filtering device left in the system, without which so many claimants would succeed that the system would be destroyed.

It is not certain that enough facts can be found for the purpose. A study of a number of draft boards in the Chicago area made after Seeger indicates that sincerity is not determined by any objective tests, no matter what the words of the statute provide, and that Seeger has had no impact on whatever subjective criteria are applied. ${ }^{97}$ The study concluded that "Seeger simply cannot be lived with at the local board level. Partly because of lack of competence and partly because of hostility, the case is ignored." ${ }^{98}$ It does not seem, then, that statutory

96 It is possible that the Court was not terrified by this argument because of confidence that the Justice Department assistance available to appeal boards guaranteed a sufficiently exact determination of sincerity. However, the 1967 revision of the Act, 50 U.S.C. App. $\$ 456(j)$ (1967), eliminated this comprehensive scheme, and draft boards now will have nothing to work with save what the registrant puts on the record. If the Seeger Court held as it did in reliance on such procedural backstops to control the swarm of claimants which the Government suggested would descend upon elimination of the Supreme Being restriction, then it might be reluctant now to dispense with the hypothetical safeguards afforded by "in any form."

97 Rabin, Do You Believe in a Supreme Being-The Administration of the Conscientious Objector Exemption, 1967 Wis. L. Rev. 642, 671, 679. It should be noted that this study was made before the 1967 revision, discussed supra note 96.

$98 \mathrm{Id}$. at 671 . One registrant, whose religious views were similar to Seeger's, encountered skepticism from the head of his local board and asked if the chairman had ever heard of the Seeger case. The chairman replied that he had and, so far as he knew, "Siebert" was still in jail. Id. at 666 .

The problems facing the conscientious objector at the local board level have been succinctly summarized by Marvin Karpatkin, Esq., an attorney who has handled numerous objector claims including the case of Captain Dale Noyd, note 120 infra:

Those of us who practice in the field find an astonishing iguorance and hostility, on the part of many local boards and on the part of some Selective Service administrators, to the requirement that all conscientious objectors be recognized as directed by the Seeger decision. ... The ambiguities of Form 150, the absence of proper and informative direction to local board members and the total lack of due process impose continuing pressure upon registrants and their attorneys to make their views sound as traditional as possible, in order to qualify.

Rarely indeed does a Selective Service registrant with Seeger-like views have a fair opportuuity for reasoned dialogue concerning his views and his claim with any Selective Service official having decision-making powers. Now that the Department of Justice hearings have been eliminated, the only face-to-face confrontation which a claimant has is with his local board-assuming that he is not trapped into a no-reopening situation where he never even gets any hearing. At the local board he is denied counsel by explicit prohibition of regulations and may have witnesses only at the board's discretion. No transcript is kept and 
criteria of an ostensibly objective character have a great deal of effect on the determination of sincerity. While it would be comforting to suppose that a sound and nondiscriminatory test, if one could be found, might help local boards, clearly the elimination of an unsound and discriminatory test will not hinder them.

Most damaging to any effort by the Government to preserve "in any form" as the last defense against a flood of exemptions, even assuming arguendo that proof of an impending deluge would suffice to retain the pacifist requirement, is the lack of effect of Seeger on the number of exemptions granted. The Selective Service System does not have records of the number of conscientious objector claims made at the local board level, but it does keep figures on the number of exemptions finally granted. There was no perceptible increase in that number in the thirteen months following Seeger. ${ }^{99}$ Furthermore, only 20,200 out of $32,640,000$ registrants are classified as conscientious objectors, 0.065 percent of the total. ${ }^{100}$ What weight these data should be given is not certain, but they do suggest that the present number of recognized exemptions could be multiplied several times before either the Selective Service System or the national defense would be jeopardized. ${ }^{101}$

there is little way that he can protect against an erroneous or biased entry in the minutes of board action on his claim. The board's determinations are then subject to only the narrowest "any rational basis in fact" judicial review. There is no appearance of any kind permitted-by either registrant, counsel or witnesses -before the appeal boards, and there are no opinions issued or explanations of any kind accompanying appeal board action; also there is reason to believe that some appeal boards do not even meet to deliberate on each case, but simply pass the papers around.

Memorandum from Marvin Karpatkin, Esq., Oct. 14, 1968, on file in the offices of the Virginia Law Review. The hostility of local boards is further illustrated by the Marshall Commission's finding that in one state fifty-five percent of all local board members thought that conscientious objectors should not be deferred at all. MarshaxL Commission Report 108-09 (1967).

99 Comment, The Conscientious Objector and the First Amendment: There But For The Grace of God ..., 34 U. CHr. L. Rev. 79, 89 n.49 (1966), citing letter from Kenneth H. McGill, Chief of the Research and Statistics Division, Selective Service System, April 6, 1966.

$100 \mathrm{ld}$. at $88 \mathrm{n} .46$.

101 In Hoclstadt, The Right to Exemption From Military Service of a Conscientious Objector to a Particular War, 3 Harv. Crv. Lib.-Civ. Rights L. Rev. 1 (1967), it is calculated from figures in the Marshall Commission Report that the manpower lost to the military through exemptions and claims under section $456(\mathrm{j})$ as of September, 1966, was at most $0.15 \%$ of the total registered, hardly an ominous statistic.

The British experience in World War II has been regarded as evidence that both the system and the nation would survive abandonment of all tests of sincerity. The British statute imposed neither tests of religion nor of pacifism; a registrant needed only to be conscientiously opposed to military service. A system of review boards, employing 
Elimination of the "Supreme Being" restrictive classification in Seeger resulted in no such multiplication, and it is not likely that the Government could show that the number of exemptions resulting from elimination of "in any form" would constitute a "grave abuse, endangering a paramount interest." There is even less reason to suppose that the Government could meet the additional requirement of Sherbert $v$. Verner-a showing that any alternative form of regulation, such as permitting selective objectors to try to prove their claims, would endanger the Selective Service System. ${ }^{102}$ The requirement that ouly complete pacifists are eligible for a conscientious objector exemption is therefore not an administrative necessity, but rather an arbitrary device to control the number of exemptions granted without regard to the sincerity of those who claim exemption. Such a classification is constitutionally infirm, and only extremely convincing proof that it is necessary to the preservation of the conscription system should immunize it from attack. Such proof does not appear to exist. If the Government wishes to save the restrictive classification, it will have to develop other arguments for the purpose.

One possible approach, closely related to the administrative necessity argument, is to contend that, even if the recognition of a right to selective objection would not of itself flood the system, the door, once opened to admit the selective objector, could not then be closed on anyone else. While this more subtle in terrorem defense should not be entertained without first putting the Government to a showing of the

judicial procedures, was established to hear claims and to classify registrants for noncombatant duty, civilian alternative service, or for unconditional exemption-a category not presently provided in this country. Over 60,000 claims were made, 43,000 of which were granted, or about $0.5 \%$ of a total registration of $8,123,000$. See D. HAYES, THE Challenge of Conscience 382-83 (1949); see generally J. Cornelu, The Conscientious Objector and the LaW 119-138 (1943); M. Sibley \& P. Jacob, Conscription of ConSCIENCE 2-7 (1952).

The differences between the nature of the threat faced by the United Kingdom in World War II and that faced by the United States in 1968, and the popular responses thereto, make any conclusions based on an extrapolation from the United Kingdom statistics extremely hazardous. The British system may be of more interest for its procedures than for its results. Rabin, supra note 97, compares the system with the present American one, and believes the most important difference to be the complete separation in the United Kingdom of the machinery of conscription from that of exemption. The American system gives authority to exempt to the very functionaries who are obliged to meet quota requirements; it is not surprising that some conflict of interest results.

102 For a selection of proposed alternatives to conscription, see THE DRAFT (S. Tax ed. 1967), particularly Oi, Costs and Implications of an All-Volunteer Army, id. at 221 . 
nature and number of the additional classes of possible claimants whose exemption, it is feared, would destroy the system, the argument lacks merit even if such a showing were made. Once Congress has chosen to draw a line between the extremes of no exemption and uncontrolled exemption, those who attack the congressional classification need only show that it is improper or irrational with respect to themselves. If the Court, in cases involving due process and equal protection for juveniles ${ }^{103}$ and for indigents in criminal appeals, ${ }^{104}$ has not been obliged to say how extensive such persons' rights ultimately may be in holding that they are greater than formerly was recognized, a selective objector should not be compelled to show how far Congress must extend the exemption to assert that Congress should have gone farther than it did. ${ }^{105}$ If the exemption is really designed to protect those citizens who otherwise would be confronted with a choice between imprisonment and violation of paramount religious beliefs, subject only to the absolutely unavoidable limitations imposed by administrative necessity, then a selective objector need only show that he is faced with that choice and that the restriction in the statute which forces the choice upon him is not administratively necessary.

\section{The Marsball Commission Report}

In its 1967 Report on the draft, ${ }^{106}$ the Marshall Commission insisted that selective objection was necessarily mere political opposition and refused to consider the Just War doctrine. ${ }^{107}$ The Commission also reported that "legal recognition of selective pacifism could open the doors to a general theory of selective disobedience to law," and perceived but dim distinction between conscientious opposition to participation in a particular war and conscientious refusal to pay a particular tax. ${ }^{108}$ The Commission ignored a fundamental difference between the two kinds of protest. On the one hand, under the present tax system, governmental acquiescence in an individual's refusal to support an objectionable program or activity would create insuperable administrative problems. ${ }^{109}$ In the absence of a feasible alternative to the present sys-

${ }^{103}$ See In re Gault, 387 U.S. 1 (1967).

104 See, e.g., Griffin v. Illinois, 351 U.S. 12 (1956).

105 See generally Tussman \& tenBroek, supra note 90.

${ }^{106}$ See note 72 supra.

107 Id.

108 Marshall Commission Report 50 (1967); cf. Giannella, Religious Liberty, Nonestablisbment, and Doctrinal Development, 80 HaRv. L. REv. 1381, 1409 (1967).

109 When an individual withholds all or part of his tax in conscientious protest 
tem of universal income taxation as a means of collecting the general revenue, an individual's payment of taxes may be conipelled. Refusal to participate in a particular war, on the other hand, entails no comparable administrative problems in effectuating the conscientious objection, and alternative routes exist by which the individual can fulfill his personal service obligation. One proposal considered by the Commission stipulated that a selective objector could be assigned nonconıbatant duty or civilian alternative service, as is provided in the present law for exempted pacifist objectors. ${ }^{110}$ The Commission did not object to the administrative feasibility of this proposal, but was "unable to see the morality" of allowing a nonpacifist to avoid combatant service in an "unjust" war under these provisions. ${ }^{111}$ The inability must stem from refusal to consider religion as a possible motivation for selective objection, as no distinction can be drawn between alternative or noncombatant service performed by a religious pacifist and the same service performed by a religious nonpacifist.

The Commission was also concerned about the effect of selective pacifism on the norale and effectiveness of the armed forces. ${ }^{112}$ It felt that a determination of the justness or unjustness of a particular war could be made only by one actually participating in it, and that the sudden conscientious withdrawal from the war of troops already in combat would involve great risks to everyone. ${ }^{113}$ The Commission's inference is unimpeachable, but its premise is open to doubt. If such an exemption were allowed at all, it would probably be claimed upon registration or by subsequent application to a local board, like the vast majority of pacifist exemptions. Those claimed after induction would clearly be liable to stricter control, as are pacifist claims made by men already in uniform. Furthermore, it would be surprising if foxholes were found to be a breeding ground for pacifism, any nore than they are said to be for atheism. In any event, it is no argument against allowing an exemption for selective objectors to say that in

against a certain government activity, there is no administratively feasible way to pass on the particular diminution in revenue to the particular activity objected to. The diminution, as well as any tax paid, will be passed on proportionately to all governmental operations, so that an individual withholding part of his tax will still be supporting the objectionable activity, and on withholding part or all of his tax will fail to carry his share of those government expenses to which he does not object. The nature of the tax system prevents effective refusal to support only a particular activity.

11050 U.S.C. App. 454 (1967); 32 C.F.R. $\$ \$ 1622.11,1622.14$ (1968).

111 Marshall Commission Report 50 (1967).

112 Cf. United States v. Schwimmer, 279 U.S. 644 (1929).

113 Marshati Commission Report 50-51 (1967). 
some circumstances, predictable and subject to administrative control, such an exemption might not be feasible.

A recent comment on dissent to the war in Vietnam suggests that it may be impossible to make a truly conscientious selective objector fight at all in a war he considers unjust, ${ }^{114}$ a practical consideration Congress may have had in mind when it created the original exemption for pacifist sectarians. ${ }^{115}$ In light of this consideration, the Commission's concern is better met by exempting selective objectors long before they reach the battle zone that by denying them the exemption altogether. ${ }^{116}$

\section{Constitutional Crossfire}

The selective objector's right to an exemption has been asserted in only two cases to date, United States $v$. Kurki117 and Noyd v. McNamara ${ }^{118}$ with inconclusive results. Kurki's selective objection claim was discussed only by the district court; his appeal was disposed of on other grounds altogether. ${ }^{119}$ In Noyd an Air Force captain on active

114 The New Republic, Jan. 6, 1968, at 23-26.

115 See Mansfield, supra note 57, at 41.

116 The Commission added a further consideration which led it to reject the concept of selective objection based on the Just War doctrine:

Forcing upon the individual the necessity of making that distinction-which would be the practical effect of taking away the Government's obligation of making it for him-could put a burden heretofore unknown on the man in uniform and even on the brink of combat. . . .

Marshall Commission Report 50-51 (1967). The Commission's solicitude requires no comment.

117384 F.2d 905 (7th Cir. 1967), cert. denied, 390 U.S. 926 (1968).

118378 F.2d 538 (10th Cir.), cert. denied, 389 U.S. 1022 (1967).

119 Kurki registered for the draft before the Seeger decision; not believing himself legally qualified for an exemption, he did not sign the conscientious objector declaration on the registration form. Neither did he appeal his local board's decision to classify him I-A. His conscientious objector claim was raised for the first time in a motion to dismiss an indictment brought against him for failure to report for induction. At that time he submitted an affidavit stating that as he did not believe in a Supreme Being and did not oppose all wars he had not thought himself eligible for exemption until after he heard of the Seeger decisions. His motion to dismiss was based on a claim of excusable neglect, couched in terms taken from Seeger. The motion itself was dismissed, the court holding in part that

in attempting to place himself within the Seeger test ... as to the meaning of the phrase "religious training and belief" ... he asks the court to place a new interpretation on that portion of the same statute which requires a conscientious opposition to war in any form. In effect, Kurki urges this court to adopt . . . a "particular war" test. . . . The court has carefully scrutinized the Seeger case and finds absolutely no authority for such a test.

This court cannot adopt such a test which flies in the face of the language 
duty sought reclassification through Air Force channels, was denied it, and subsequently refused to obey a lawful order to train pilots en route to Vietnam. ${ }^{120}$ But if a selective objection case devoid of such complications reaches the Supreme Court in which a religious basis for objection is adequately demonstrated, it is submitted that, under Seeger, the Court will have to countenance an infringement of religious liberty or eliminate the "war in any form" limitation by either statutory interpretation or a direct constitutional holding.

The discreet methodology employed in Seeger implies, anıong otlier things, a desire on the part of the Court to avoid a constitutional interpretation of the conscientious objector provision of the draft law. It is possible, as sonie commentators have suggested, ${ }^{121}$ that the Court treads gingerly in this area in fear that Congress might repeal the exemption altogether if its scope were extended too far by the judiciary. The Court might then find itself unable to compel Congress to reinstate the exemption on constitutional grounds. This possibility is the greatest threat to any recognition at law of a right to selective objection, and the status of such objection cannot be asserted without considering the validity and implications of that threat.

\section{Background of the Legislative Grace Theory of Exemption}

There is some consensus aniong commentators that an exenption for

of 50 U.S.C.A. App. $\$ 456(j)$ and defies the intent of Congress when it set up the conditions for the conscientious objector exemption.

255 F. Supp. 161, 165 (E.D. Wisc. 1966).

Evidently Kurki did not feel any effort beyond the mere statement of his claim was required to place himself within the scope of Seeger, as he offered no additional constitutional arguments in support of that claim.

120378 F.2d 538 (10th Cir. 1967). Noyd's attempts in civilian courts to compel Air Force recognition of his status as a selective objector were dismissed for lack of jurisdiction, because he had not exhausted all possible remedies within the military establishment. The Supreme Court denied certiorari, 389 U.S. 1022 (1967), and Noyd was convicted by a general court martial for refusing to obey a lawful order to train a student pilot on orders to Vietnam.

The procedural differences between selective service classification of civilians and military re-classification of personnel on active duty, and the additional complication of Noyd's refusal to obey an order, will probably provide adequate grounds for a final disposition of his case without ever reaching the merits of his selective objector claim. See Comment, God, The Army, and Judicial Review: The In-Service Conscientious Objector, 56 CALIF. L. Rev. 379, 393-95 (1968). Appeal is being taken from the court martial's verdict, however, and it is remotely possible that Noyd's case will afford the Supreme Court a vehicle for passing on selective objection if it chooses to do so.

121 See note 37 supra. 
conscientious objectors is not constitutionally compelled, ${ }^{122}$ although it has been suggested that the status of the exemption should be reexamined in the light of recent decisions by the Court in the first amendment area. ${ }^{123}$ In any event, the theory that conscientious objector exemptions are a matter of legislative grace finds support as early as the congressional debates over the Bill of Rights, when a proposed clause exempting "those religiously scrupulous" from the bearing of arms was omitted from the finished amendment. ${ }^{124}$

The first judicial language on the subject appears in Jacobson v. Massachusetts, decided in 1905. ${ }^{125}$ The issue there was whether Jacobson could be required to submit to vaccination despite religious scruples; the first Justice Harlan wrote that he could be, adding that a person could also be compelled to go to war in defense of his country, regardless of his religious convictions. ${ }^{126}$ The statement is dictum, but it has been durable.

In United States $v$. Macintosh, in which Chief Justice Hughes wrote the dissent discussed above, ${ }^{127}$ the decision turned on the intended meaning of the oath of allegiance required of naturalized citizens. Macintosh stipulated that his allegiance to the United States was subordinate to his allegiance to God and that he could not swear he would necessarily defend the Umited States against all its enemies. Justice Sutherland condemned the suggestion that the Constitution reserved such a prerogative to Macintosh or to anyone else. He stated that

122 One analysis of the cases concludes,

We may therefore accept as the law today that both Congress and the states have the constitutional power to compel all to engage in armed combat, irrespective of individual religious contrary convictions; and to impose for refusal such lesser sanctions as exclusion from citizenship, public controlled educational institutions, and the practice of the law.

L. Pfeffere, Church, State and Freedom 621 (rev. ed. 1967).

123 See, e.g., Galanter, Religious Freedoms in the United States: A Turning Point?, 1966 Wis. L. Rev. 217; Comment, The Conscientious Objector and the First Amendment: There But For The Grace of God . . ., 34 U. CHr. L. Rev. 79 (1966).

124 The surviving part of the record of the debate gives the opinion of one representative that "he would always leave it to the benevolence of the Legislature, for, modify it as you please, it will be impossible to express it in such a manner as to clear it of ambiguity." It is not known whether this prescient concern was the reason for the failure of the clause to appear in the finished amendment, but the fact that it was for some reason omitted is taken to show that the framers intended no constitutional mandate for the exemption. Mansfield, supra note 57 , at $59-60$, quoting 1 Ansals of Congress 751 (1789).

125197 U.S. 11 (1905).

126 Id. at 29.

127283 U.S. 605 (1931). See text at notes 43-44 supra. 
"[t] he privilege of the native-born conscientious objector to avoid bearing arms comes not from the Constitution, but from the acts of Congress." 128

Determination of the merits of Macintosh's claim did not require exposition of the Constitution. But however gratuitous Justice Sutherland's dictum may have been, it was taken as dispositive in Hamilton $v$. Regents, ${ }^{129}$ where students at the University of California challenged the state's power to compel their participation in ROTC programs as a condition of attending the state university. The Court relied on Macintosh for the principle that the students had no constitutional right to avoid the bearing of arms, and held that since attendance at the state university itself was not compulsory, the students had to observe the university's curriculum requirements or go elsewhere. The holding depended in large part upon the fact that no pledge to engage in actual military service was involved in taking the required ROTC course, and this element considerably limits the effect of the case.

The most recent case in the Macintosh line is In re Summers, ${ }^{130}$ where the Court upheld the Illinois Bar Association's refusal to admit a pacifist. Summers was obliged to swear to defend the Illinois constitution, which required militia service in time of war and provided no exemptions from that service. The Illinois supreme court held that Summers' pacifist convictions made it impossible for him to swear the oath and that consequently he could not be admitted to the bar. This ruling was upheld in a five-four decision by the Supreme Court which, again relying heavily on Macintosh, found that such an exclusion worked no deprivation of constitutionally guaranteed religious liberty.

Summers is the only case in this line whose holding is squarely based on constitutional interpretation, and it would seen controlling on that account. However, the Court relied heavily upon Macintosh in deciding as it did, and in 1946 Macintosh was overruled. Macintosh had been ostensibly a case of statutory interpretation; in Giroudard $v$. United States ${ }^{131}$ the Court re-interpreted the same statute and concluded that Congress had not intended to exclude conscientious objectors froni naturalized citizenship. The Girouard Court did not address the question of whether Congress could have done so, as Macintosh has been

128 Id. at 624.

129293 U.S. 245 (1934).

130325 U.S. 561 (1945).

131328 U.S. 61 (1946). 
held to establish, but Girouard also contains dicta which contradict those of Macintosh as squarely as its holding reverses the earlier case. ${ }^{132}$

It is a safe operating premise, then, that Macintosh is not good law, and the holding in Hamilton, narrow to begin with, is weak as well to the extent it depends on the constitutional dicta of Macintosh. Summers, however, is not so easily wished away. Though weakened by the staleness of Macintosh, it is not dead as precedent. On the other hand, Professor Mansfield has written that even if Summers were unimpaired it could be read merely as a statement that in some circumstances Congress can compel combatant service under the war power-a statement quite different than a holding that Congress can do so at its pleasure, in time of peace, and in disregard of the conscientious scruples of those it would punish for disobedience. ${ }^{133}$

In any event, the most that can be said for the Macintosb-Summers line of cases is that it lends support to the proposition that there may not be an absolute right to avoid the bearing of arms, but does not establish that proposition. The least that can be said for the cases is that they are not only stale and inconclusive in themselves but also irrelevant in the light of more recent decisions construing the religion clauses of the first amendment.

\section{Constitutional Compulsion of the Exemption}

While an exemption for some conscientious objectors exists, the problem for a religiously motivated selective objector is one of obtaining protection for his religious scruples equal to the protection the statute gives those of pacifist objectors. If the exemption were withdrawn altogether, however, religious pacifist objectors would also be affected and an effort to find a constitutional mandate for their exemption would be based on the free exercise clause alone.

Cantwell v. Connecticut ${ }^{134}$ offers the classic statement of the doctrinal limitation on free exercise: while it is absolutely beyond the authority of the state to limit or control freedom of behief, freedom to act on that belief is necessarily subject to regulation for the protection of society. The same doctrine was applied by Chief Justice Waite in

132 E.g., id. at 68, where Justice Douglas' language echoes the Macintosb dissent:

Throughout the ages, men have suffered death rather than subordinate their allegiance to God to the authority of the State. Freedom of religion guaranteed by the First Amendment is the product of that struggle.

133 Mansfield, supra note 57 , at 66.

134310 U.S. 296 (1940). 
Reynolds $v$. United States, ${ }^{135}$ where a Mormon defended polygamy as an exercise of his religion. The Court did not concede a religious character to the practice; it was made clear, however, that the first amendment, even if properly invoked, would not liave helped Reynolds. Justice Waite speculated that if polygamy could be justified as a religious exercise the Court would have no leeway if it were confronted with a similar justification for human sacrifice or suttee, and declared that "[1] aws are made for the government of actions, and while they cannot interfere with mere religious belief and opinions, they may with practices." 136

If Reynolds had been decided after Sherbert $v$. Verner, it would have been interesting to discover the nature of the paramount interest to which polygamy would be a "grave abuse;"137 in other areas, lowever, that interest has been stated clearly enough. In Prince $v$. Massachusetts, ${ }^{138}$ for instance, a mother was convicted under a state child labor law when she allowed her nine-year old child to distribute Jehovah's Witnesses literature on the street at night. The Court sustained the conviction, holding that the activity, although religious, could be prohibited because of the state's overriding regulatory interest in child welfare. And in Braunfeld v. Brown $n^{139}$ a Sabbatarian merchant attacked a state Sunday-closing law, but lost on the grounds that the law furthered a legitimate state interest in providing one uniform day of rest and left Mr. Braunfeld perfectly free to observe lis own Sabbath, albeit at a financial loss.

Cases of this sort look to the regulation of socially offensive religious practices. Withdrawal of the conscientious objector exemption, however, would constitute social compulsion of religiously offensive practices. It is one thing to protect a social policy by curtailing religious activity which threatens it; it may be quite another thing to compel an individual to participate in the social policy by affirmative actions which violate his conscience. The effects of the two types of regulation are not the same, and the regulations themselves should not be judged by the same standards. As Chief Justice Stone wrote,

however rigorous the state may be in repressing the commission of acts which are regarded as injurious to the state, it may well stay its

13598 U.S. 145 (1878).

136 Id. at 166.

137 See text at note 92 supra.

138321 U.S. 158 (1944).

139366 U.S. 599 (1961). 
hand before it compels the commission of acts which violate the conscience. ${ }^{140}$

It was precisely to this latter category of regulation, where affirmative action is compelled in violation of an individual's conscience, that the Court addressed itself in Sberbert $v$. Verner. ${ }^{141}$ There a woman who refused employment requiring her to work on her Sabbath was denied unemployment benefits under a statute which conditioned eligibility on availability for any suitable employment. The Court held that

to condition the availability of benefits upon this appellant's willingness to violate a cardinal principle of her religious faith effectively penalizes the free exercise of her constitutional liberties. ${ }^{142}$

The principle of Sherbert is stronger in some ways when applied to the problem of compelling exemptions for conscientious objectors. Mrs. Sherbert was not required to violate her faitli; she was merely denied a benefit if she failed to do so. The strong language the Court used in her case indicates language stronger still might be expected if she had been placed, as an unexempted conscientious objector would be, under an affirmative obligation to act contrary to her religious obligations. ${ }^{143}$

On the other hand, the relief Mrs. Sherbert sought obviously did not threaten to jeopardize the administration of the secular scheme involved. An argument alleging such a threat to the Selective Service System might be raised against the asserted constitutionally compelled consci-

140 Stone, supra note 27 , at 268 . The Chief Justice also commented that there may be and probably is a very radical distinction between compelling a citizen to refrain from acts which he regards as moral but which the majority of his fellow citizens and the law regard as immoral or unwholesome to the life of the state, on the one hand, and compelling him on the other hand to do affirmative acts which he regards as unconscientious and immoral. . . . [C]ompelling the citizen to refrain from doing an act which he regards as moral and conscientious does not do violence to his conscience; but conscience is violated if he is coerced into doing an act which is opposed to his deepest

Id. convictions of right and wrong.

141374 U.S. 398 (1963).

142 Id. at 406 . It may not be useful to attempt to reconcile Sherbert and Braunfeld at all; clearly Mr. Braunfeld lost trade to his competitors if he observed his own Sabbath as well as the statutory day of rest, while a similar consequence to Mrs. Sherbert was held unconstitutional. The statute did leave Mr. Braunfeld free to observe his own Sabbath if he wished to, however, a freedom effectively demed to Mrs. Sherbert by the Sourh Carolina regulation.

143 See Brodie \& Southerland, Conscience, The Constitution, and The Supreme Court: The Riddle of United States v. Seeger, 1966 WIs. L. Rev. 306, 321. 
entious objector exemption. However, this kind of argument has been dealt with in an analogous context and in a way entirely suitable to the settlement of the conscientious objector problem. A Mrs. Jenison, nuindful of the Biblical injunction "judge not lest ye be judged," refused jury duty and was convicted for it in a state court. The Supreme Court reviewed the case and remanded it for reconsideration in the light of Sberbert, which had just been handed down. ${ }^{144}$ On remand, the Minnesota supreme court found no adequate showing of any overriding state interest and held that unless

the indiscriminate invoking of the First Amendment poses a serious threat to the effective functioning of our jury system, any person whose religious convictions prohibit compulsory jury duty shall henceforth be exempt. ${ }^{145}$

Whether or not the Court could find a constitutional mandate for the conscientious objector exemption turns upon the application given Sberbert. That case appears to confine limitations on free exercise to situations where the religious practice constitutes a "grave" abuse, "endangering paramount interests," and where the state can show that there is no alternative form of regulation which would protect the state interest without limiting free exercise. ${ }^{140}$ When the regulation takes the form of compelling the individual affirmatively to violate his religious tenets, rather than merely requiring him to refrain from religious actions inimical to some secular value, it is reasonable to suppose that the state's burden of demonstrating both the paramountcy of its interest and the absence of alternative means of serving it will be increased. ${ }^{147}$

144 In re Jenison, 375 U.S. 14 (1963).

145 In re Jenison, 267 Minn. 136, 137, 125 N.W.2d 588, 589, rev'g, 265 Minn. 96, 120 N.W.2d 515 (1963).

146 See text at note 89 supra.

147 One commentator has analyzed the distinction between state restriction of conscientious action and state compulsion of acts repugnant to conscience in terms of the blood transfusion issue, and concludes that a person may be required to submit to transfusions contrary to his rehigious convictions only where the state's interest in the welfare of minor children requires the parent to be kept alive. Galanter, Religious Freedoms in the United States: A Turning Point?, 1966 Wrs. L. Rev. 217. See In re Brooks' Estate, 32 Ill. 2d 361, 205 N.E.2d 435 (1965). Mrs. Brooks had no minor children, and, while conscious, refused transfusions; she had even signed a release to the hospital from all hability for failure to give transfusions. A conservator was appointed while Mrs. Brooks was unconscious, and he authorized transfusions. The treatment was not successful and, after Mrs. Brooks' death, the appointment of the conservator and his authorization of the transfusion were held violative of the de- 
The state's interest in being able to defend itself is undeniably paramount. ${ }^{148}$ It is empirically clear, however, that an exemption for pacifist rehigious objectors does not endanger that interest or impair the conscription system. It follows under Sherbert that an exemption at least as broad as that afforded by the present statute is constitutionally required, whether Congress provides it or not. If an administrative necessity argument were raised against compelling an exemption broad enough to include all religious objectors, pacifist or selective, the approach used in In re Jenison would dispose of the problem. ${ }^{149} \mathrm{It}$ appears, therefore, that if the Court responded to a due process attack on "war in any form" by extending the present statute to include religious selective objectors, the free exercise clause as applied in Sherbert would require invalidation of any retaliatory effort by Congress to repeal the exemption altogether.

\section{ConCLUSION}

The initial obstacle to a consideration of the constitutional merits of a selective objection claim is the notion that no selective objector can cedent's constitutional rights. This decision appears to carry the "paramount interest" test as far as it will go.

148 See United States v. O'Brien, 391 U.S. 367 (1968), discussed note 92 supra.

149 Giving any exemption at all to religious objectors has been attacked as a violation of the establishment clause. Cf. Donnici, supra note 37, at 37-38. However, a definitive answer to this objection is provided by Justice Brennan's concurring opinion in School Dist. of Abington v. Schempp, 374 U.S. 203, 230 (1963). Justice Brennan spoke of the "paradox" presented by "the logical interrelationship between the Establishment and Free Exercise Clauses [which] may produce situations where an injunction against an apparent establishment must be withheld in order to avoid infringement of rights of free exercise." Id. at 247. The necessity of the paradox to avoid free exercise violations compels a construction of the estabhshment clause which directs the government to be neutral but not hostile towards rehigion. See Zorach v. Clauson, 343 U.S. 306 (1952); Everson v. Board of Educ., 330 U.S. 1 (1947). Reasoning from this construction, Justice Brennan stated that neutrality is violated by Government sponsorship of religious exercises in public schools, but that refusal to provide chaplains for prisoners or soldiers "cut off from all civilian opportumities for public communion" would be hostility, not neutrality, as would denial of exemption for mimisters and conscientious objectors. 374 U.S. at 299. Since the estabhishment compels only neutrality, and governmental failure to provide the exemption would be hostility, it follows that the clause does not force Congress to refrain from exempting rehigious objectors.

A contrary view might be based on Professor Kurland's unitary reading of the first amendment, which would permit no classification whatever in terms of religion. P. Kunland, Religion and the Latw 112 (1962). The Court implicitly rejected that approach in Schempp, however, and its conceptual inadequacy has been demonstated by Professor Schwartz, who finds the establishment clause limited to instances where religion is sought to be imposed, a problem not presented by exemption of religious objectors. Schwartz, No Imposition of Religion: The Establishment Clause Value, 77 YALE L.J. 692, 693-701 (1968). 
base his claim on "religious training and belief." It is clear, however, under the broad interpretation given that phrase in Seeger, that some selective objectors may qualify, and to deny them exemption as a matter of law arbitrarily discriminates among forms of religious belief.

The only grounds for excluding religious selective objectors from the exemption would be the threat their recognition would present to the administration of the Selective Service System. There is no evidence that the number of such claims would be so great that the nation's ability to maintain an army would be imperiled. The remaining problen 1 would be whether the present system is equipped to winnow the sincere claims from the spurious; and existing procedures, insofar as they are adequate to handle the claims of pacifist objectors, are also adequate to handle those of selective objectors.

Once the possibility of religious motivation for selective objection is granted, and the administrative necessity arguments against recognizing that form of objection are overcome, there is no reason why a due process attack on the present statute should not be sustained. The Seeger decision, viewed in terms of what the Suprene Court did rather than in terms of what the Court said it was doing, would permit no other resnlt.

The more delicate question is whether the Court would agree to hear such a case at all, given its possible reluctance to extend the scope of the exemption one more step beyond the limits Congress clearly intended to impose upon it, at the risk of public outcry in time of war and possible legislative elimination of all exemptions whatever. That risk was run in Seeger, but not until a conflict between two circuits and a petition from the Government brought the problem squarely before the Court. A similar situation might be required to goad the Court into hearing a case of selective objection on its constitutional merits.

It is clear, however, that such a case deserves to be lieard, and that ample law exists which would compel recognition of a religious selective objector's claim to exemption. It is equally clear that no interest of the state requires the infringement of first amendment rights involved in continued failure to recognize such a claim. In the event the Court recognizes the claim, there slould be no doubt of its duty under the Constitution to compel exemption of all sincere religious objectors, even absent a statute providing such an exemption. 